\title{
KOMPOSISI JENIS DAN KELIMPAHAN ZOOPLANKTON DI PERAIRAN DESA TUMBU-TUMBU JAYA, KABUPATEN KONAWE SELATAN
}

\section{Composition and Abundance of Zooplankton in Tumbu-Tumbu Jaya Seawaters, South Konawe Selatan}

\author{
Abdur Muh. Rifsaldi ${ }^{1}$, Wa Nurgayah ${ }^{2}$, Emiyarti $^{3}$ \\ ${ }^{1}$ Mahasiswa Ilmu Kelautan \\ Fakultas Perikanan dan Ilmu Kelautan Universitas Halu Oleo \\ Jl. HEA Mokodompit Kampus Bumi Tridharma Anduonohu Kendari 93232 \\ ${ }^{2}$ Surel: nurgayah_fish@yahoo.com \\ ${ }^{3}$ Surel: emiyarti@ymail.com
}

\begin{abstract}
Abstrak
Keberadaan zooplankton di perairan dapat dimanfaatkan sebagai pakan alami bagi biota laut sehingga penyediaan data terkait komposisi jenis dan kelimpahan zooplankton di suatu perairan sangat diperlukan. Penelitian ini bertujuan untuk mengetahui komposisi jenis dan kelimpahan zooplankton di Perairan Desa Tumbu-Tumbu Jaya. Pengambilan sampel dilakukan pada bulan Maret-Mei 2019 dengan pendekatan metode random sampling. Hasil analisis menunjukkan bahwa terdapat 13 jenis zooplankton di lokasi studi yaitu Copepoda, Tortanus, Schmackeria, Nauplius, Apocyclops, Oithona, Echinocamptus, Nitocra, Acartia, Balanus, Favella, Codonellopsis dan Pinctada. Komposisi jenis tertinggi terdapat di ekosistem mangrove dengan presentase $40 \%$ pada kisaran suhu $29-30^{\circ} \mathrm{C}$, kecepatan arus $0,01-0,03 \mathrm{~m} / \mathrm{det}$, salinitas $29-30$ ppt, pH 7, DO 5,7-6. Sedangkan kelimpahan zooplankton tertinggi ditemukan pada ekosistem terumbu karang yang mencapai $91 \mathrm{ind} / \mathrm{L}$ pada kisaran suhu $28-30^{\circ} \mathrm{C}$, kecepatan arus 0,01-0,05 m/det, salinitas 30-31 ppt, pH 7, DO 5,7-6.
\end{abstract}

Kata Kunci: Komposisi jenis, Kelimpahan Zooplankton, Desa Tumbu-Tumbu Jaya

\begin{abstract}
Abstrak
Zooplankton is the source of life for most of aquatic organisms which is used as natural feed. The provision of data related to the composition and abundance of zooplankton in a seawaters is very necessary. This study aimed to determine the composition and abundance of zooplankton in Tumbu-Tumbu Jaya seawaters. Random sampling method was applied to determine site and sample data which was conducted from March to May 2019. Results of the analysis showed that there were 13 types of zooplankton at the study area i.e Copepoda, Tortanus, Schmackeria, Nauplius, Apocyclops, Oithona, Echinocamptus, Nitocra, Acartia, Balanus, Favella, Codonellopsis and Pinctada. The highest species composition was found in mangrove ecosystems reached $40 \%$. The temperature at the area ranged $29-30^{\circ} \mathrm{C}$, current velocity ranged $0.01-0.03 \mathrm{~m} / \mathrm{sec}$, salinity ranged $29-30 \mathrm{ppt}, \mathrm{pH} 7$, and DO ranged 5.7-6. The highest abundance of zooplankton was found in coral reef ecosystems reached $91 \mathrm{ind} / \mathrm{L}$. In coral reef area, the temperature, current velocity, salinity, $\mathrm{pH}$ and DO ranged $28-30^{\circ} \mathrm{C}, 0.01-0.05 \mathrm{~m} / \mathrm{sec}, 30-31 \mathrm{ppt}, 7$, and $5.7-6$ respectivelly.
\end{abstract}

Keywords: Composition, Abundance Zooplankton, Tumbu-Tumbu Jaya

\section{Pendahuluan}

Plankton merupakan suatu organisme mikroskopis yang hidupnya melayang-layang atau mengapung di perairan baik laut maupun tawar disebabkan oleh arus. Peranan organisme ini sangat penting, salah satunya sebagai sumber makanan bagi organisme lainnya yang hidup pada tingkatan tropik yang lebih tinggi dalam perairan. Plankton dapat dibedakan menjadi dua golongan besar yaitu fitoplankton (plankton nabati) dan zooplankton (plankton hewani). Zooplankton berperan sebagai konsumen primer dalam ekosistem perairan (Nontji, 2008).
Keberadaan zooplankton dapat ditemukan dihampir seluruh habitat perairan dengan kelimpahan dan komposisinya yang berbeda. Kelimpahan dan komposisinya bergantung pada kondisi suatu lingkungan perairan (Moniharapon et al, 2014). Sebaran dan keanekaragaman zooplankton tergantung pada ketersediaan makanan, keragaman lingkungan, adanya tekanan ikan pemangsa/ predator, suhu air, polutan, oksigen terlarut, hembusan angin yang memicu pergerakan air serta interaksi antara faktor biotik dan abiotik lainnya (Alexander, 2004). 
Zooplankton berperan sebagai konsumen tingkat pertama pada ekosistem perairan, fungsinya sebagai penyalur energi dari fitoplankton sebagai produsen primer selanjutnya zooplankton dimakan oleh organisme ditingkat tropik yang lebih tinggi. Keberadaanya di perairan, dapat dimanfaatkan sebagai pakan alami ikan-ikan yang terdapat disuatu perairan sehingga penyediaan data terkait jenis serta kelimpahan zooplankton di perairan sangat diperlukan (Said, 2017).

Perairan Desa Tumbu-Tumbu Jaya merupakan perairan yang tepat berada di Perairan Teluk Kolono, dimana perairan ini umumnya dimanfaatkan oleh masyarakat dalam berbagai aktifitas diantaranya mencari ikan, budidaya ikan dan berbagai aktifitas lainnya. Keberadaan ekosistem (mangrove, lamun dan terumbu karang) di perairan tersebut menunjukan perairan yang cukup produktif, sehingga penelitian yang berkaitan dengan komposisi jenis dan kelimpahan zooplankton pada ekosistem perairan Desa Tumbu-Tumbu Jaya perlu dilakukan untuk memberikan informasi bagi peneliti selanjutnya serta masyarakat dapat mengoptimalkan pemanfaatan sumber daya hayati di perairan tersebut.

Tujuan penelitian adalah untuk mengetahui komposisi jenis dan kelimpahan zooplankton di Perairan Desa Tumbu-Tumbu Jaya, Kabupaten Konawe Selatan. Selanjutnya sebagai informasi awal untuk mengetahui kondisi zooplankton yang ada di perairan tersebut.

\section{Bahan dan Metode}

Penelitian ini telah dilaksanakan pada bulan Maret 2019 - Mei 2019 bertempat di Perairan Desa Tumbu-Tumbu Jaya, Kabupaten Konawe Selatan, Provinsi Sulawesi Tenggara. Lokasi penelitian zooplankton dilakukan ditiga stasiun, yaitu pada ekosistem mangrove, ekosistem lamun dan ekosistem karang. Analisis komposisi jenis zooplankton, kelimpahan zooplankton dan analisis DO dilakukan di Laboratorium Unit Produktivitas Lingkungan Perairan Fakultas Perikanan dan Ilmu Kelautan UHO.

Alat dan bahan yang digunakan dalam penelitian ini di sajikan berdasarkan 3 kegiatan yaitu pengambilan sampel plankton di lapangan, pengukuran kualitas air dan identifikasi laboratorium yaitu : Kamera, Stopwatch, Kompas bidik, Thermometer, Layang arus, Hendrofractometer, Modifikasi Winkler, $\mathrm{pH}$ indikator, Planktonet ukuran mata jaring 30$50 \mathrm{~nm}$, Mikroskop, SRC, GPS digital, Alat Tulis, Ember (10 liter), Perahu, Botol, Kertas label, Buku kunci identifikasi zooplankton, Botes Lizeth (2003) dan Buku identifikasi Zooplankton, Yamaji (1966). Bahan yang digunakan dalam penelitian ini yaitu lugol untuk mengawetkan sampel plankton dan larutan $\mathrm{MnSO}_{4}$ untuk mengikat oksigen terlarut (DO).

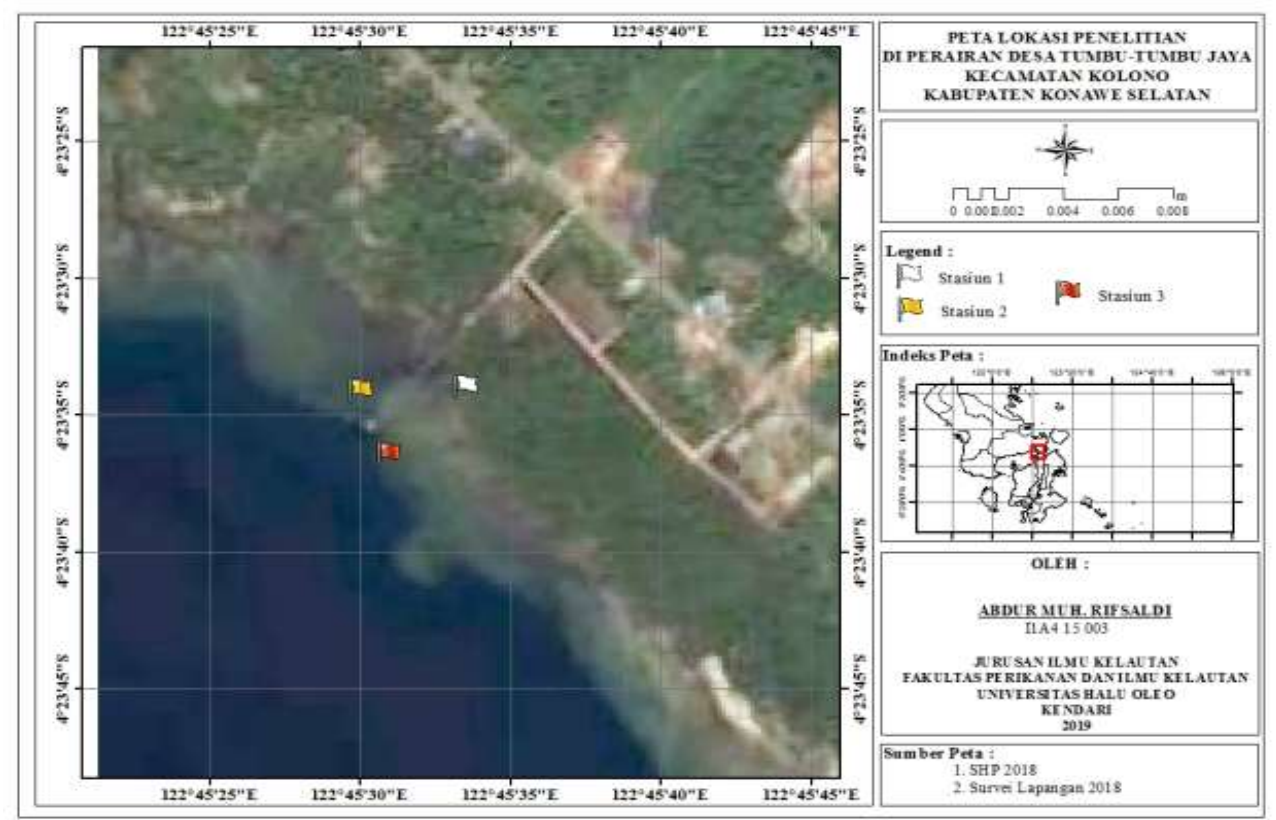

Gambar 1. Peta Lokasi Penelitian 
Prosedur penelitian ini meliputi tahapan kegiatan persiapan observasi lapangan, penentuan stasiun, pengambilan sampel air dan pengukuran parameter pendukung, analisis data serta penyusunan laporan akhir. Studi literatur dan survei awal lapangan untuk mengetahui gambaran yang jelas mengenai kondisi umum lokasi penelitian, serta menyiapkan peralatan yang digunakan dalam penelitian.

Penentuan stasiun penelitian ditentukan ditiga stasiun berdasarkan daerah yang terdapat ekosistem mangrove, lamun dan karang di Perairan Desa Tumbu-Tumbu Jaya, dapat dilihat sebagai berikut : Stasiun I Berada di

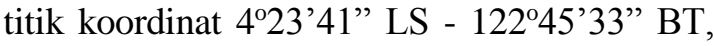
stasiun ini berada pada ekosistem mangrove. Stasiun II Berada dititik koordinat 4 $23^{\prime}$ ' $42^{\prime \prime}$ LS - 122045'31" BT, stasiun ini berada pada ekosistem lamun dan stasiun III Berada dititik koordinat $4^{\circ} 23^{\prime} 45^{\prime \prime}$ LS - 122 $45^{\prime} 30^{\prime \prime}$ BT, stasiun ini berada pada ekosistem terumbu karang.

Pengambilan sampel dilakukan selama 1 bulan. pengambilan sampel dilakukan sebanyak 2 kali dengan interval waktu pengambilan sampel tiap 1 kali dalam 2 minggu, dengan menggunakan planktonet, berukuran mata jaring 30-50 nm. Pengambilan sampel zooplankton dilakukan pada tiga stasiun yaitu pada ekosistem mangrove, ekosistem lamun dan ekosistem karang. Pengambilan sampel dilakukan pada pukul 05.00 WITA, 17.00 WITA dan 23.00 WITA.

Pengambilan sampel zooplankton dilakukan dengan mengambil 100 liter air laut kemudian disaring menggunakan planktonet, hasil saringan selanjutnya ditampung ke dalam botol bervolume $152 \mathrm{ml}$, kemudian diawetkan dengan diberi beberapa tetes lugol, untuk selanjutnya diidentifikasi jenis dan kelimpahannya di Laboratorium Produktifitas dan Lingkungan Perairan dengan menggunakan mikroskop dengan pembesaran 10-40x.

Pengukuran parameter perairan, dilakukan dengan pengukuran secara langsung di lapangan dan pengukuran di laboratorium. Pengukuran ini meliputi suhu, Kecerahan, Kecepatan Arus, salinitas, pH dan DO. Metode pengambilan data parameter perairan sebagai berikut:

- Suhu

Pengukuran suhu dilakukan pada permukaan perairan dengan mencelupkan
Thermometer langsung ke dalam perairan pada tiap stasiun dan mencatat nilai yang tertera pada alat tersebut.

- Kecepatan Arus

Pengukuran arus dilakukan disetiap stasiun pengamatan. Pengukuran kecepatan arus dilakukan dengan melepas layang-layang arus dengan stopwatch dan melihat arah arus dengan kompas bidik dengan mengamati pergerakan layang-layang arus dan mencatatnya. Kecepatan arus diketahui dengan cara menghitung selang waktu (t) yang dibutuhkan layang arus untuk menempuh jarak (s) dengan rumus:

$\mathrm{V}=\frac{\mathrm{s}}{t}$

Keterangan :

$\mathrm{V}=$ Kecepatan arus (m/detik)

$\mathrm{s}=$ Jarak tempuh layang-layang arus (m)

$\mathrm{t}=$ Waktu yang digunakan (detik)

- Kecerahan

Pengukuran kecerahan dilakukan dengan cara menurunkan secchi disc sampai hilang dari pandangan. Menurunkan sepertiga meter dan kemudian perlahan-lahan mengangkat secchi disc sampai terlihat kembali, gerakan secchi disc ke atas dan ke bawah sampai titik hilang yang tepat ditemukan. Pasang jepitan di tali pada titik tali masuk ke air. Mencatat hasil pengukuran.

- Salinitas

Pengukuran salinitas dilakukan dengan cara meneteskan air laut pada alat Handrafactometer kemudian membaca nilai skala yang tertera pada alat tersebut.

- Oksigen Terlarut (DO)

Pengukuran oksigen terlarut dilakukan dengan pengambilan sampel DO menggunakan botol volume $\pm 300 \mathrm{ml}$ yang bersih dan tidak tembus cahaya matahari langsung kemudian saat pengisian di botol hindari terjadinya turbulensi dengan gelembung udara yang masuk ke dalam botol. Pengambilan sampel DO dilakukan disetiap stasiun penelitian.

- $\mathrm{pH}$

Pengukuran $\mathrm{pH}$ air laut menggunakan $\mathrm{pH}$ indikator di permukaan Perairan pada tiap stasiun. Caranya yaitu dengan mencelupkan $\mathrm{pH}$ indikator ke air lalu mengangkat $\mathrm{pH}$ indikator kemudian mencatat nilai yang tertera pada alat tersebut

Analisis data dilakukan untuk beberapa data yang dibutuhkan yaitu menghitung 
komposisi jenis dan kelimpahan digunakan rumus sebagai berikut:

Untuk menghitung komposisi jenis zooplankton pada masing-masing stasiun dihitung dengan menggunakan rumus Odum (1996) :

$\mathrm{Pi}=\frac{n i}{N} \times 100 \%$

Keterangan :

$\mathrm{Pi}=$ Komposisi jenis $(\%)$

$\mathrm{ni}=$ Jumlah individu tiap jenis ke-i (ind)

$\mathrm{N}=$ Jumlah total individu (ind)

Analisis pada zooplankton dilakukan dengan menghitung kelimpahan zooplankton digunakan SRC (Sedwick rafter counter) dengan metode sensus. Penghitungan kelimpahan zooplankton dilakukan dengan menggunakan rumus APHA (2005) sebagai berikut:

$\mathrm{K}=\frac{N}{A c} \times \frac{A t}{V S} \times \frac{V t}{A s}$

Keterangan :

$\mathrm{K}=$ Kelimpahan plankton (ind $\mathrm{L}^{-1}$ )

$\mathrm{N}=$ Jumlah plankton yang diamati (sel)

$A c=$ Luas amatan $\left(\mathrm{mm}^{2}\right)$

At $=$ Luas penampang permukaan SRC $\left(\mathrm{mm}^{2}\right)$

$\mathrm{Vs}=$ Volume konsentrat dalam SRC (ml)

$\mathrm{Vt}=$ Volume konsentrat botol contoh $(\mathrm{ml})$

$\mathrm{As}=$ Volume air disaring $(\mathrm{L})$

\section{Hasil dan Pembahasan}

Hasil penelitian yang telah dilakukan pada daerah pengamatan di Perairan Desa Tumbu-Tumbu Jaya ditemukan 13 jenis zooplankton, terlihat bahwa komposisi jenis zooplankton terbesar ditemukan pada ekosistem mangrove (Stasiun I) ditemukan 11 jenis zooplankton dengan presentase tertinggi $40 \%$ (Gambar 2) dibandingkan ekosistem lamun (Stasiun II) dan ekosistem karang (Stasiun III), hal ini menunjukan bahwa kondisi lingkungan ekosistem mangrove baik untuk komposisi jenis zooplankton. Komposisi jenis zooplankton yang mendominasi Perairan Desa TumbuTumbu Jaya yaitu zooplankton jenis Nauplius berasal dari kelas Crustacea hidup dengan baik dan tersebar hampir diseluruh badan perairan. Hal ini sesuai pernyataan Romimotarto dan Juwana (2004), zooplankton dari kelas Crustacea di perairan memiliki komposisi jenis yang tinggi dikarenakan Crustacea mampu menyebar pada wilayah yang luas serta mampu beradaptasi pada kondisi lingkungan perairan yang kurang baik.

Rata-rata hasil pengukuran parameter perairan dilakukan di titik stasiun pengamatan yang merupakan keterwakilan dari 3 ekosistem yang berbeda yaitu ekosistem mangrove, lamun dan karang di Perairan Desa Tumbu-Tumbu Jaya, beberapa parameter perairan dari ketiga stasiun (mangrove, lamun dan karang) tidak menunjukan perbedaan yang besar, kisaran suhu perairan berkisar $28-30{ }^{\circ} \mathrm{C}$, kecepatan arus berkisar 0,01-0,05 M/det, kecerahan perairan $100 \%$, salinitas $29-31$ ppt dan $\mathrm{pH}$ untuk semua stasiun yaitu 7 . Kisaran yang berbeda ditunjukan pada parameter DO untuk nilai DO stasiun I berkisar 5,7-6 mg/L, stasiun II berkisar 5,3-5,7 $\mathrm{mg} / \mathrm{L}$ dan stasiun III berkisar 4,5-4,9 mg/L. Sanusi (2004), mengatakan bahwa nilai oksigen terlarut yang berkisar antara 5,45-7,00 mg/L cukup baik bagi kehidupan organisme perairan. Kelimpahan fitoplankton sebagai makanan zooplankton juga menunjukan kisaran yang berbeda, untuk stasiun I berkisar 168-415 ind/L, stasiun II berkisar 271-626 ind/L dan kelimpahan fitoplankton pada stasiun III berkisar 69-636 ind/L.

Perbedaan komposisi jenis zooplankton setiap stasiun penelitian terjadi karena adanya perbedaan kondisi perairan dan karakteristik lingkungan yang mempengaruhi kehidupan zooplankton. Hal ini sesuai dengan pernyataan Paramudhita et al (2018), perbedaan jumlah dan jenis genus zooplankton setiap perairan dapat terjadi karena perbedaan kondisi perairan dan karakteristik lingkungan yang berkaitan dengan kemampuan bertahan hidup masingmasing zooplankton. Di Perairan Desa Tumbu-Tumbu Jaya zooplankton jenis Nauplius memiliki presentase tertinggi disemua stasiun penelitian (Gambar 2, 3 dan 4) mengindikasikan bahwa jenis tersebut dapat menyesuaikan diri dengan kondisi perairan, komposisi jenis zooplankton mendominasi suatu perairan karena sesuai dengan habitat tempat hidupnya salah satunya adalah karena ketersediaan makanan. Hal ini sesuai dengan pernyataan Ara dan Hiromi (2009), faktor ketersediaan makanan merupakan salah satu komponen penting terhadap keberadaan zooplankton disuatu perairan. 


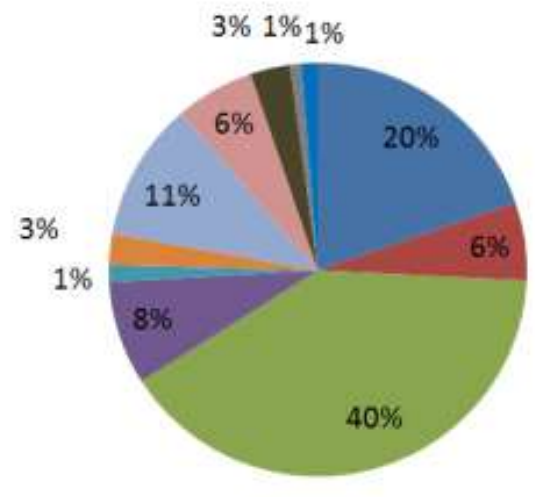

- Copepoda

- Tortanus

Nauplius

- Apocyclops

Echinocamptus

E Favella

= Codonellopsis

= Acartia

- Nitocra

- Schmackeria

- Balantus

Gambar 2. Histogram Nilai Komposisi Jenis Zooplankton Stasiun I berdasarkan Jenis di Perairan Desa Tumbu-Tumbu Jaya.

Gambar 3. Histogram Nilai Komposisi Jenis Zooplankton Stasiun II berdasarkan Jenis di Perairan Desa Tumbu-Tumbu Jaya.

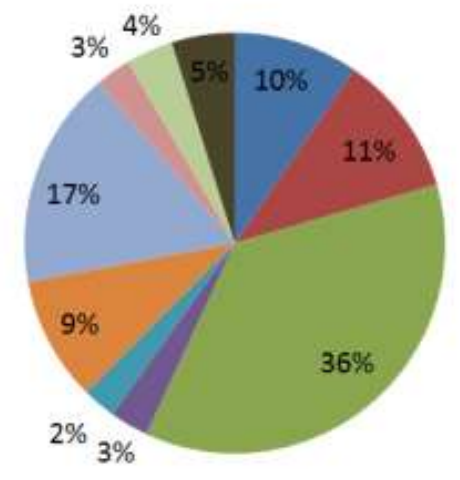

$$
\begin{aligned}
& \text { = Copepoda } \\
& \text { = Tortanus } \\
& \text { = Nauplius } \\
& \text { = Apocyclops } \\
& =\text { Echinocamptus } \\
& =\text { Favella } \\
& \text { = Codonellopsis } \\
& =\text { Acartia } \\
& =\text { Oithona } \\
& \text { - Nitocra }
\end{aligned}
$$

Gambar 4. Histogram Nilai Komposisi Jenis Zooplankton Stasiun III berdasarkan Jenis di Prairan Desa Tumbu-Tumbu Jaya. 


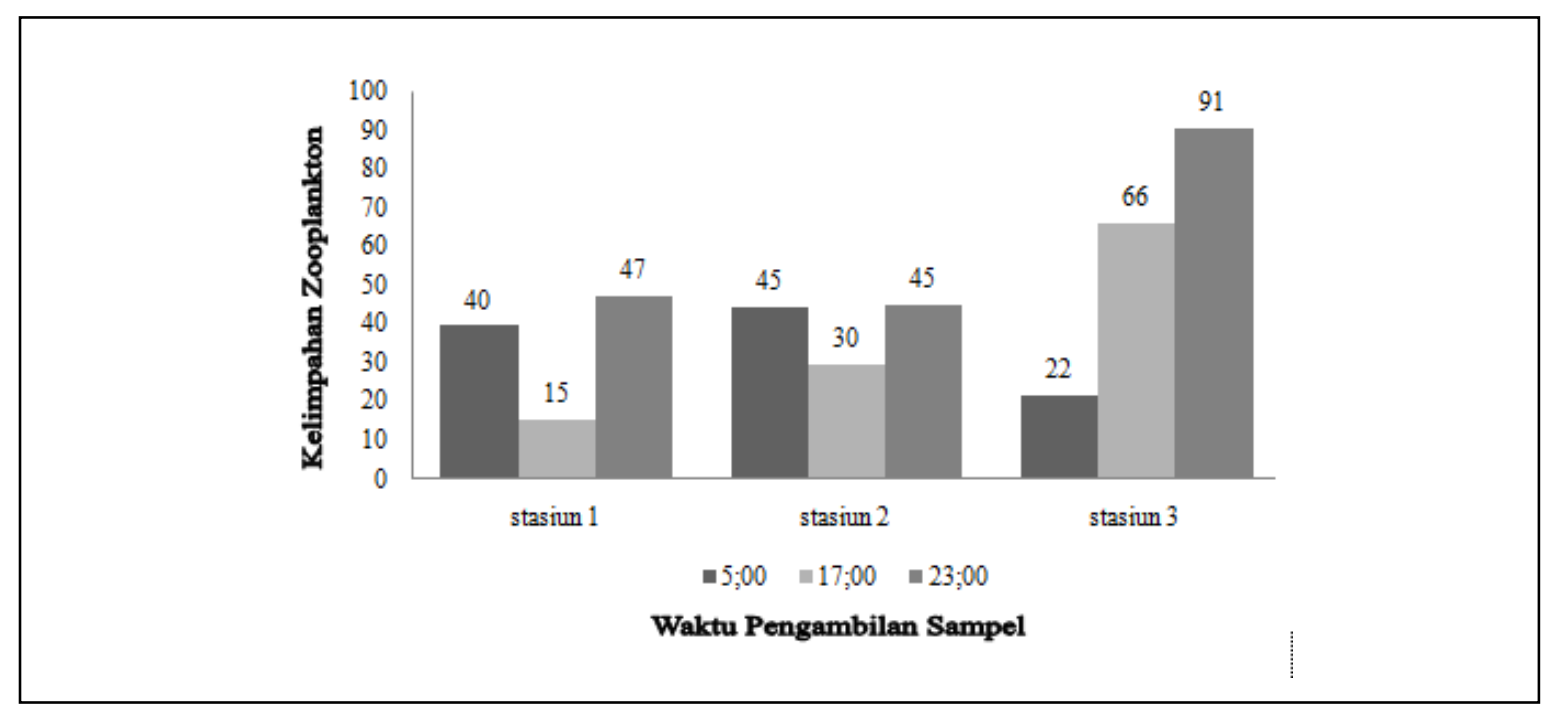

Gambar 5. Histogram Nilai Kelimpahan Zooplankton di Perairan Desa Tumbu-Tumbu Jaya.

Komposisi jenis zooplankton terendah ditemukan pada stasiun I dan II dengan presentase $1 \%$, stasiun I ditemukan jenis Schmackeria, Echinocamptus dan Balanus sedangkan stasiun II ditemukan jenis Echinocamptus dan Pinctada. Hasil penelitian (Gambar 2, 3 dan 4) dari ketiga stasiun menunjukan jenis Schmackeria dan Balanus ditemukan hanya terdapat di stasiun I sedangkan Pinctada ditemukan hanya pada stasiun II. Hal ini menunjukan bahwa komposisi Jenis zooplankton dipengaruhi oleh kondisi perairan, zooplankton hanya dapat hidup dan berkembang dengan baik pada kondisi perairan yang sesuai. Hal ini sesuai pernyataan Raza'i (2017), bahwa komposisi jenis zooplankton disuatu perairan sangat erat kaitannya dengan perubahan lingkungan perairan baik fisik, kimia dan biologis, jika kondisi lingkungan dan ketersediaan fitoplankton tidak sesuai dengan kebutuhan zooplankton maka zooplankton tidak dapat bertahan hidup dan akan mencari kondisi lingkungan yang sesuai. Begitupun sebaliknya, zooplankton dapat hidup dan berkembang dengan baik pada kondisi perairan yang sesuai.

Kelimpahan zooplankton di Perairan Desa Tumbu-Tumbu Jaya berkisar antara 1591 ind/L. Kelimpahan zooplankton tertinggi ditemukan pada stasiun III yaitu 91 ind/L (Gambar 5), stasiun III terletak pada ekosistem karang yang masih tergolong baik pada perairan tersebut. Tingginya nilai kelimpahan zooplankton pada ekosistem karang, diduga karena dipengaruhi oleh kondisi parameter fisika dan kimia lingkungan Perairan Desa Tumbu-Tumbu Jaya. Pada umumnya suhu, kecepatan arus, kecerahan, salinitas dan $\mathrm{pH}$ di Perairan Desa Tumbu-Tumbu Jaya tidak terdapat perbedaan yang jauh antara stasiun I, stasiun II dan Stasiun III. Perbedaan terlihat dari hasil penelitian untuk kelimpahan fitoplankton stasiun III berkisar 169-636 ind/L kandungan DO stasiun III lebih rendah dari stasiun I dan II yaitu berkisar 4,5-4,9 $\mathrm{mg} / \mathrm{L}$ dan masih tergolong baik untuk kehidupan zooplankton. Hal ini sesuai dengan pernyataan Chusnan (2018), plankton dapat hidup dengan baik pada konsentrasi oksigen terlarut lebih dari 3 mg/L. Kurangnya DO pada stasiun III disebkan karena tingginya kelimpahan zooplankton yang memanfaatkan DO dalam proses metabolisme. Hal ini sesuai dengan pernyataan Dian et al (2014), rendahnya nilai DO di perairan disebabkan karena sebagian besar oksigen dikosumsi oleh mikroorganisme diantaranya zooplankton yang memanfaatkan DO dalam proses metabolisme bahan organik. Selain itu perbedaan kelimpahan zooplankton pada stasiun III diduga dipengaruhi oleh waktu pengambilan sampel yaitu saat malam hari di Pukul 23:00, menunjukan kelimpahan zooplankton pada perairan tersebut melimpah, disebabkan saat malam hari zooplankton melakukan migrasi vertikal menuju permukaan untuk mencari makan. Hal ini sesuai dengan pernyataan Bagja et al (2012), aktifitas zooplankton menumpuk di permukaan perairan pada waktu keadaan gelap (malam hari) menunjukan zooplankton mulai mencari makan. 
Kelimpahan zooplankton yang berbeda pada tiap stasiun penelitian juga dipengaruhi adanya perbedaan parameter perairan pada tiap stasun. Perbedaan parameter perairan disebabkan karena waktu pengambilan sampel serta perbedaan lingkungan disetiap lokasi pengambilan sampel. Hal ini sesuai dengan pernyataan Dian et al (2014), perbedaan parameter perairan disebabkan karena perbedaan waktu pengambilan maupun perbedaan kondisi lingkungan disetiap stasiun. Kehidupan zooplankton sangat dipengaruhi oleh parameter fisika dan kmia perairan. Hal ini sesuai dengan pernyataan Yuliana dan Fasmi (2017), pertumbuhan dan perkembangan zooplankton dipengaruhi oleh parameter fisika dan kimia perairan.

Kelimpahan zooplankton juga dipengaruhi oleh beberapa faktor diantaranya perubahan lingkungan dan adanya predator. Hal ini sesuai pernyataan Steinberg et al (2002), migrasi vertikal zooplankton sangat bergantung terhadap variasi perubahan lingkungan misalnya cahaya, suhu, salinitas, oksigen, makanan dan predator. Kelimpahan zooplankton terendah terdapat pada stasiun I, pengambilan sampel di stasiun I terletak pada ekosistem mangrove, waktu pengambilan sampel dilakukan di sore hari pada pukul 17:00 WITA (Gambar 5) dan pengambilan sampel dilakukan tepat dipermukaan perairan, salah satu faktor penyebab kurangnya kelimpahan zooplankton yang didapatkan pada stasiun I karena kondisi cuaca yang masih cerah sehingga zooplankton bergerak menjauhi permukaan. Hal ini sesuai dengan pernyataan Wati et al (2019), zooplankton cenderung beradah jauh di bawah permukaan air pada siang hari dan muncul di permukaan perairan pada malam hari.

Hasil penelitian (Gambar 5) yang dilakukan terlihat bahwa kelimpahan zooplankton tertinggi cenderung berada pada stasiun III (ekositem karang) yaitu terlihat pada dua waktu pengambilan Pukul 17:00 dengan kelimpahan 66 ind/L dan Pukul 23:00 dengan kelimpahan 91 ind/L, pada Pukul 05:00 kelimpahan zooplankton stasiun III lebih rendah dari kedua stasiun yaitu $22 \mathrm{ind} / \mathrm{L}$ sedangkan stasiun I dan II berturut-turut 40 ind/L dan 45 ind/L. Kelimpahan zooplankton yang tidak merata pada tiap stasiun menunjukan bahwa kelimpahan zooplankton dipengaruhi oleh keberadaan fitoplankton yang menjadi makanannya, faktor fisik kimia perairan juga sangat mempengaruhi kelimpahan zooplankton. Hal ini sesuai pernyataan Wibowo et al (2004), kelimpahan zooplankton sangat tergantung pada kelimpahan fitoplankton, karena fitoplankton adalah makanan bagi zooplankton. Selain dipengaruhi ketersediaan makanan (fitoplankton), kelimpahan zooplankton juga sangat dipengaruhi oleh faktor lingkungan perairan yaitu faktor fisika (suhu, kecerahan dan kecepatan arus) dan faktor kimia (salinitas, $\mathrm{pH}$ dan DO).

\section{Simpulan}

Berdasarkan hasil dan pembahasan maka dapat ditarik kesimpulan mengenai perbandingan komposisi jenis dan kelimpahan zooplankton di Perairan Desa Tumbu-Tumbu Jaya sebagai berikut:

1. Komposisi jenis zooplankton terbesar terdapat pada ekosistem mangrove dengan presentase $40 \%$ zooplankton jenis Nauplius yang ditemukan dari kelas Crustacea. Sedangkan komposisi jenis zooplankton dengan presentase terendah juga terdapat pada ekosistem mangrove dan ekosistem lamun dengan presntase $1 \%$, pada ekosistem mangrove ditemukan jenis Schmackeria, Echinocamptus dan Balanus sedangkan pada ekosistem lamun ditemukan jenis Echinocamptus dan Pinctada.

2. Kelimpahan zooplankton dari hasil penelitian terbesar ditemukan pada ekosistem karang dengan kelimpahan 91 ind/L. Untuk kelimpahan zooplankton terendah ditemukan pada ekosistem mangrove dengan kelimpahan 15 ind/L.

\section{Daftar Pustaka}

Alexander, T. B. 2004. Faktor-Faktor Lingkungan Abiotik dan Keanekaragaman Plankton Sebagai Indikator Kualitas Perairan Danau Toba. Manusia dan Lingkungan. Vol. 9(2): 64-72.

APHA (American Public Health Association). 2005. Standard Methods for the Examination of Waterand Wastewater. 21th Edition. Washington DC (US): American Public Health Assosiation American Water Work Association/ Water Enviroment Federation.

Ara, K. and J. Hiromi. 2009. Seasonal variability in plankton food web 
structure and trophodynamics in the neritic area of Sagami Bay, Japan. J. of Oceanography, 65:757-779.

Bagja, B. P., Zahidah H. dan Herman H. 2012. Pola Migrasi Vertikal Diurnal Plankton Di Pantai Santolo Kabupaten Garut. Jurnal Perikanan dan Kelautan. Vol. 3(1): 81-89. ISSN : 2088-3137.

Botes, L. 2003. Phytoplankton Identification Catalogue (Globallast Monograph Series No. 7) : Saldanha Bay South Africa April 2001. Programme Coordination Unit Global Ballast Water Manapemet Programme.

Chusnan M. M. 2018. Perbandingan Keanekaragaman Dan Kelimpahan Plankton Pada Ekosistem Terumbu Karang Alami Dengan Terumbu Buatan Di Perairan Pasir Putih Situbondo. Skripsi. Universitas Islam Negeri Sunan Ampel. Surabaya.

Dian, E. F., Isdradjad S. Dan Majariana K. 2014. Kondisi perairan dan struktur komunitas makrozoobentos di Sungai Belumai Kabupaten Deli Serdang Provinsi Sumatera Utara. Depik. Vol. 3(1) : 1-9. ISSN : 2089-7790.

Moniharapon, D. Indra J. Hendri M. Sari P. Totok H. dan Augy S. 2014. Migrasi Vertikal Zooplankton Di Laut Banda. Jurnal Kelautan Nasional, 9(3): 143151.

Nontji, A. 2008. Plankton Laut. LIPI. Jakarta. Odum, E. P. 1996. Dasar-Dasar Ekologi. Edisi Ketiga (Terjemahan Ir. Tjahjono Samingan, MSc). Gajah Mada University Press. Yogyakarta. 697 hal.

Pramudhita W., Hadi E. \& Ria A. T. N. 2018. Struktur Komunitas Zooplankton di Perairan Desa Mangunharjo,

Kecamatan Tugu, Semarang. Buletin Oceanografi Marina. Vol. 7 (2) : 113120. ISSN : 2089-3507.

Raza'i, T. 2017. Identification and Density of Zooplankton as Natural Food Sources of Fish in The Waters Kampung Gisi, Tembeling, District of Bintan. Intek Akuakultur, 1 (1): 27-36.

Romimotarto K. dan Juwana S. 2004. Biota Laut: Ilmu Pengetahuan Tentang Biota Laut. Jakarta: Djambatan.

Said, T. R. 2017. Identifikasi dan Kelimpahan Zooplankton Sebagai Sumber Pakan Alami Ikan Budidaya di Perairan
Kampung Gisi Desa Tembeling Kabupaten Bintan. Intek Akuakultur. Vol. 1 (1): 27-36.

Sanusi, H. S. 2004. Karakteristik Kimiawi dan Kesuburan Perairan Teluk Pelabuhan Ratu Pada Musim Barat dan Timur. Jurnal Ilmu-Ilmu Perairan dan Perikanan Indonesia. Vol. 11(2): 93-100.

Steinberg, D. K., Goldthwait, S. A., \& Hansel, D. A. (2002). Zooplankton vertical migration and the active transport of dissolved organic and in organic nitrogen in the Sargasso Sea. Deep Sea Research I, 49, 14451461.

Wati M., Nur I. dan Indrayani. 2019. Pola Migrasi Vertikal Harian Zooplankton pada Berbagai Kedalaman Di Perairan Pulau Bungkutoko Kecamatan Abeli. Jurnal Manajemen Sumber Daya Perairan. 4(1): 61-73.

Wibowo, A. Wiryanto A.B. \& Sutomo. 2004. Zooplankton diversity, abundance and distribution in Digul waters, Arafura Sea, Papua. BIOSMART, 6 (1): 51-56.

Yamaji, E. E. 1966: Ilustration Of The Marine Plankton Of Japan. Holkusha Osaka Japan.

Yuliana dan Fasmi A. 2017. Komposisi Jenis dan Kelimpahan Zooplankton di Perairan Teluk Buli, Halmahera Timur. Jurnal Ilmiah Agribisnis dan Perikanan, $10(2)$ : 44-50. 